\title{
Structure and Development of the Intellectual Potential of the Industrial Enterprise Personnel
}

\author{
Aliya Z. Gafiyatullina ${ }^{1}$, Adeliya V. Pavlova ${ }^{2,3}$, Maria V. Vesloguzova ${ }^{3}$, Rayaz K. Takhaviev ${ }^{4}$, Ilana B. Kashirina ${ }^{5}$ \\ $\&$ Svetlana I. Ashmarina ${ }^{6}$ \\ ${ }^{1}$ Open Joint Stock Company Tatneft, Almetyevsk, Russia \\ ${ }^{2}$ Kazan Federal University, Kazan, Russia \\ ${ }^{3}$ Volga Region State Academy of Physical Culture, Sport and Tourism, Kazan, Russia \\ ${ }^{4}$ Naberezhnye Chelny Institute of Kazan Federal University, Naberezhnye Chelny, Russia \\ ${ }^{5}$ Amur State University, Blagoveschensk, Russia \\ ${ }^{6}$ Samara State University of Economics, Samara, Russia \\ Correspondence: Aliya Z. Gafiyatullina, Regulatory Research Station, Open Joint Stock Company Tatneft, \\ Mardzhani Street 82, Almetyevsk, Tatarstan, 423458, Russia. E-mail: otiz_tn@tatneft.ru
}

Received: October 24, 2014 Accepted: December 3, 2014 Online Published: December 18, 2014

doi:10.5539/res.v7n1p117 URL: http://dx.doi.org/10.5539/res.v7n1p117

\begin{abstract}
The purpose of this article is to develop the conditions of the management system improvement and the industrial enterprise personnel development. Presented article defines the intellectual potential of the enterprise personnel, its location, components and forms of appearance in the enterprise activities. The personnel intellectual potential is an important factor of scientific and technical progress and increases the efficiency of all aspects of industrial enterprise production and commercial activities. The results of the present study indicate the need to evaluate and determine the directions of the enterprise personnel intellectual potential development to achieve the strategic company's goals and creating competitive advantages. This article is intended for managers, executives, HR staff and researchers dealing with personnel development of the industrial enterprise.
\end{abstract}

Keywords: enterprise personnel, personnel intellectual potential, evaluation, management, development

\section{Introduction}

\subsection{Background}

The human's role, requirements to the workforce and to the professional training of industrial enterprise personnel are substantially changing in the present conditions of economic development (Milner, 2008; Muhamedyarov, 2008). The company's activities can be represented in the form of intellectual, innovative and productive activities, where intellectual assets makes resource base, including personnel intellectual potential, appearing as a source of productivity growth. Dynamics of changes in the business and the rapid obsolescence of the acquired knowledge continuously encourage organizations to develop the personnel intellectual potential (Stewart, 2007; Chernoles, 2008). Thus, determination of intellectual labor personnel peculiarities and development of an appropriate system ensuring a continuous process of enterprise personnel development are becoming the urgent tasks.

\subsection{International Experience Analysis of the Enterprise Personnel Management}

Analysis of trends in human resource management revealed some trends of staff involvement in the quality management process and the overall humanization of the economy (Kibanov \& Durakova, 2007). That is, enterprise personnel is not considered from the view point of resources, but as a personal integrity, which has the necessary qualifications and experience for the company, directly affecting the quality of production processes and products in the compliance with social accountability requirements.

The standard of the social management system or social accountability SA 8000: 2001 (Social Accountability) in relation to organization's personnel includes guaranteed regulations on wages, work hours, health, safety and security protection with obligatory monitoring of their realization. Such requirements are included in the quality 
management system of the organization and provide not only the efficiency and image of the company, but also the productivity of labor, and the personal impact of employees. The principle of continuous improvement is included in the basis of this standard, both in terms of organization and personnel growth.

\subsection{Status of a Problem}

Special feature of the new information society is that the labor is transforming from a means of subsistence into the way of life activity and the constant actualization of a person (Egorshin, 2011). Here the motive is not to meet the needs, but the method for realization personality's interests, creativity potential, intention to development, including the professional activities. In this regard, the person's labor management should be directed on the organization of such conditions that: firstly, become the condition for person's self-actualization in professional activities; secondly, integrate the organization's goals and objectives of the employee; thirdly, become a factor of increasing the organization's economic efficiency.

Now in Russia the problem of personnel management, social and labor relations, employment, standard of living and per capita income, quality of life (Bukhalkov, 2005; Mahankova, 2010; Noskova, 2010) have been deeply investigated. In Russian economic science relatively less studied such burning for post-industrial stage of social development issues as the transformation of social labor and the role of human factors in relation to innovation processes, staffing of scientific and technological progress and innovation processes (Bovin et al., 2009; Lavrentiev \& Sharina, 2010).

The aspects of the personnel intellectual potential dynamics, affecting the efficiency of modern organization personnel management are studied by the domestic economics in a less degree (Hadasevich, 2010). These circumstances determine the choice of the research topic and actualize the theoretical and practical aspects of improving the management of industrial enterprise personnel intellectual potential.

\subsection{The Research Hypothesis}

Analysis of the theoretical and practical developments in the aspect of this problem showed that the issues related to the management of intellectual potential of the industrial enterprise personnel remain currently understudied, which allows us to define a hypothesis: accounting, control and development of the industrial enterprise personnel intellectual potential in modern conditions increase the enterprise economic efficiency and employee's satisfaction growth.

\section{Materials and Methods}

\subsection{The Objectives of the Research}

The study pursued the following objectives: 1) the structure development of the enterprise personnel intellectual potential; 2) the introduction of development strategies and evaluation of personnel intellectual potential in the enterprise personnel management system; 3 ) the reveal of the dynamics and development trends of the personnel intellectual potential; 4) assessment of the enterprises personnel satisfaction and the techniques efficiency.

\subsection{The Basis of the Research}

The study was conducted on the basis of an oil company JSC "Tatneft". The employees engaged in intellectual and managerial activities (about 1000 people) were involved in the investigation. 96 people participated in the survey concerning the determination of personnel satisfaction with staff policy regarding the intellectual potential development.

\subsection{The Stages of the Research}

The study was conducted in three stages:

In the first stage the enterprise personnel intellectual potential was structured, there was introduced the technique of its evaluation and the development strategy was implemented into the personnel policy of the enterprise, based on the life cycle of the personnel intellectual potential.

The second stage was designed to study techniques for personnel intellectual potential assessing, to develop criteria for the assessment of its development and impact on the enterprise economic efficiency.

In the third stage personnel intellectual potential was assessed, the effectiveness of personnel development strategy was evaluated and the level of personnel satisfaction with changes in the development of the enterprise personnel was identified.

\subsection{Criteria for Evaluation}

Evaluation of the personnel intellectual potential was carried with the aid of the following criteria (Anisimova, 
2010; Grishina, 2011):

- The effectiveness from inventions and received models introduced into production;

- Cost-effectiveness of the personnel intellectual potential;

- The ratio of the proposed inventions number to the produced number;

- Qualification increase of the personnel intellectual potential;

- The ratio of the personnel intellectual potential number to the total number of employees;

- Personnel intellectual potential profitability.

\section{Results}

\subsection{Structure Determination of the Enterprise Personnel Intellectual Potential}

The enterprise personnel intellectual potential is a part of the intellectual capital, which reflects the level of education, professionalism, qualification level, skills, workers innovation culture, as well as creativity and ability to thinking process and self-development, that gives the opportunity to use the intellectual capital of the organization in the best way and is manifested in the update, progress and value-added assets of the organization (Fig. 1).

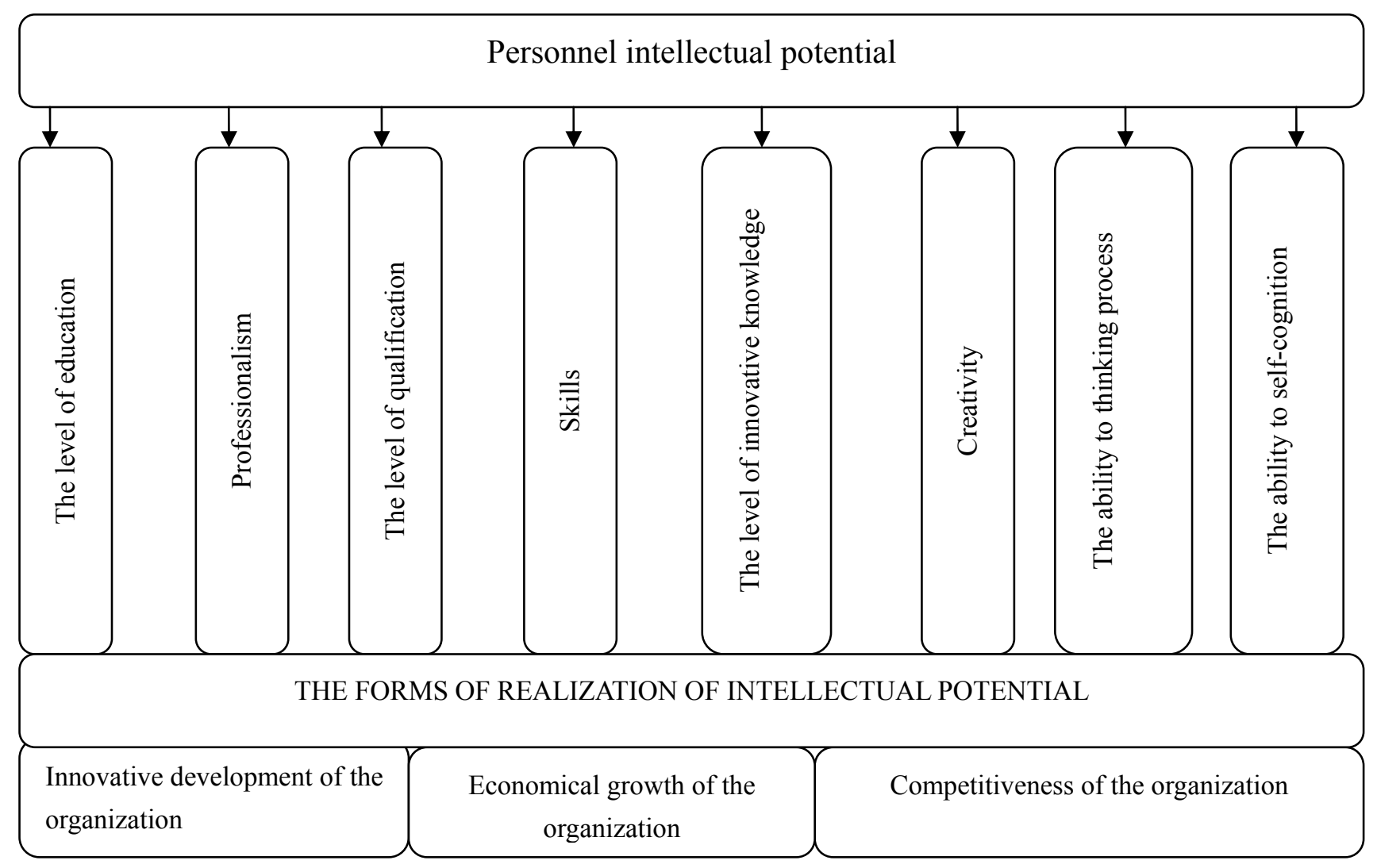

Figure 1. The structure and forms of realization of the organization intellectual potential

Enterprise personnel intellectual potential has a number of system properties: productivity, efficiency, structural organization, heterogeneity, variability, stability, adaptability, compatibility, lability, creativity, controllability, that makes the characteristics of the good "personnel" unique, and has a direct impact on the competitiveness of the latter and allows to develop strategy that builds the assets through intellectual capital.

\subsection{The Life Cycle of the Intellectual Potential of the Industrial Enterprise Personnel}

Author's redetermined the lifecycle stages of the industrial enterprises personnel intellectual potential they include: formation, accumulation, realization, value increase and diffusion, which allow to convert organization's resources to the personnel intellectual potential value growth (Fig. 2). 


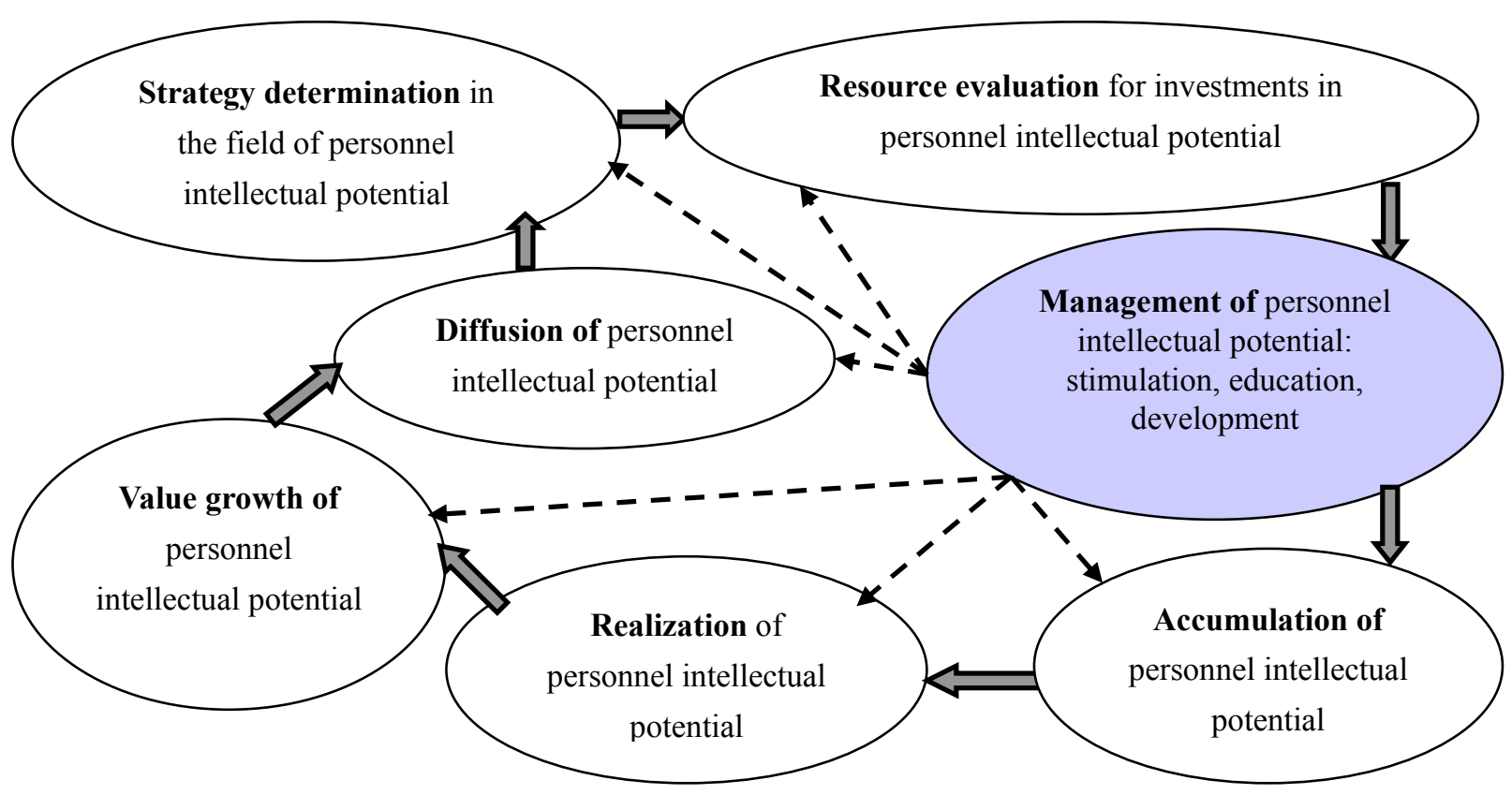

Figure 2. Life cycle of the intellectual potential of the industrial enterprise personnel

Accumulation value of the personnel intellectual potential is based on the investments made in corporate training programs, management and incentives, taking into account the personal attitudes of the staff. The implementation of the personnel intellectual potential is in creation and promotion of innovative products, services or technologies in the market, that provide competitive advantages of the industrial enterprise. The value increase of the personnel intellectual potential is carried out from the standpoint of profitability, return on investment and growth of innovative activity in general. The diffusion of the personnel intellectual potential means the distribution and including the existing staff resources into the industrial enterprise activity, as long as the return of staff has an economic effect. The final stage of the life cycle is the need for policy change of personnel management in order to improve the efficiency of the industrial enterprise personnel intellectual potential use.

\subsection{Managing the Development of the Intellectual Potential of the Industrial Enterprise Personnel}

Considering the system of management of the personnel intellectual potential as an innovation, we can say that it has all the properties of the innovation. Firstly, changes in the management system of the personnel intellectual potential aimed to solve specific problems in accordance with the development strategy of the organization. Secondly, it is impossible to determine in advance how they result in. Thirdly, the changes in management system of personnel intellectual potential may cause conflicts connected with the resistance of workers, their rejection of innovations due to the fear of possible risks, situations of uncertainty associated with continue studies and retraining, possible changes in staff schedule. And finally, changes in the management system of the personnel intellectual potential, as a rule, tend to cause response changes in the rest of organization subsystems as they relate to the main component of the organization - its employees.

Thus, the control system of the personnel intellectual potential goes ontogenically through all the stages of the innovation process, this fact leads to an objective need for the development and realization the technique for the organization activity from the perspective of level using and realization of the personnel intellectual potential, which determines its real condition, possible prospects for further development, "bottlenecks", in other words the possibility to plan activities focused on improving personnel management.

Measurement and valuation techniques for industrial enterprise personnel must include: the distinguishing of personnel intellectual potential of corporation; identification of significant parameters of realization of corporation intellectual potential; determination of specific parameters of intellectual potential realization, associated with the corporate industry specifics; implementation of advanced forecasts of realization of enterprise personnel intellectual potential. 
Theses developed in this research were tested in "Tatneft" (a major oil company comprises 21.4 thousand employees) in order to assess the personnel intellectual potential and work-out the development strategy which will be able increase the operational efficiency.

On the basis of the reported data there was carried out the calculation of some indicators of JSC "Tatneft" personnel intellectual potential and there was received a comprehensive assessment for the period 2011-2013. (Fig. 3)

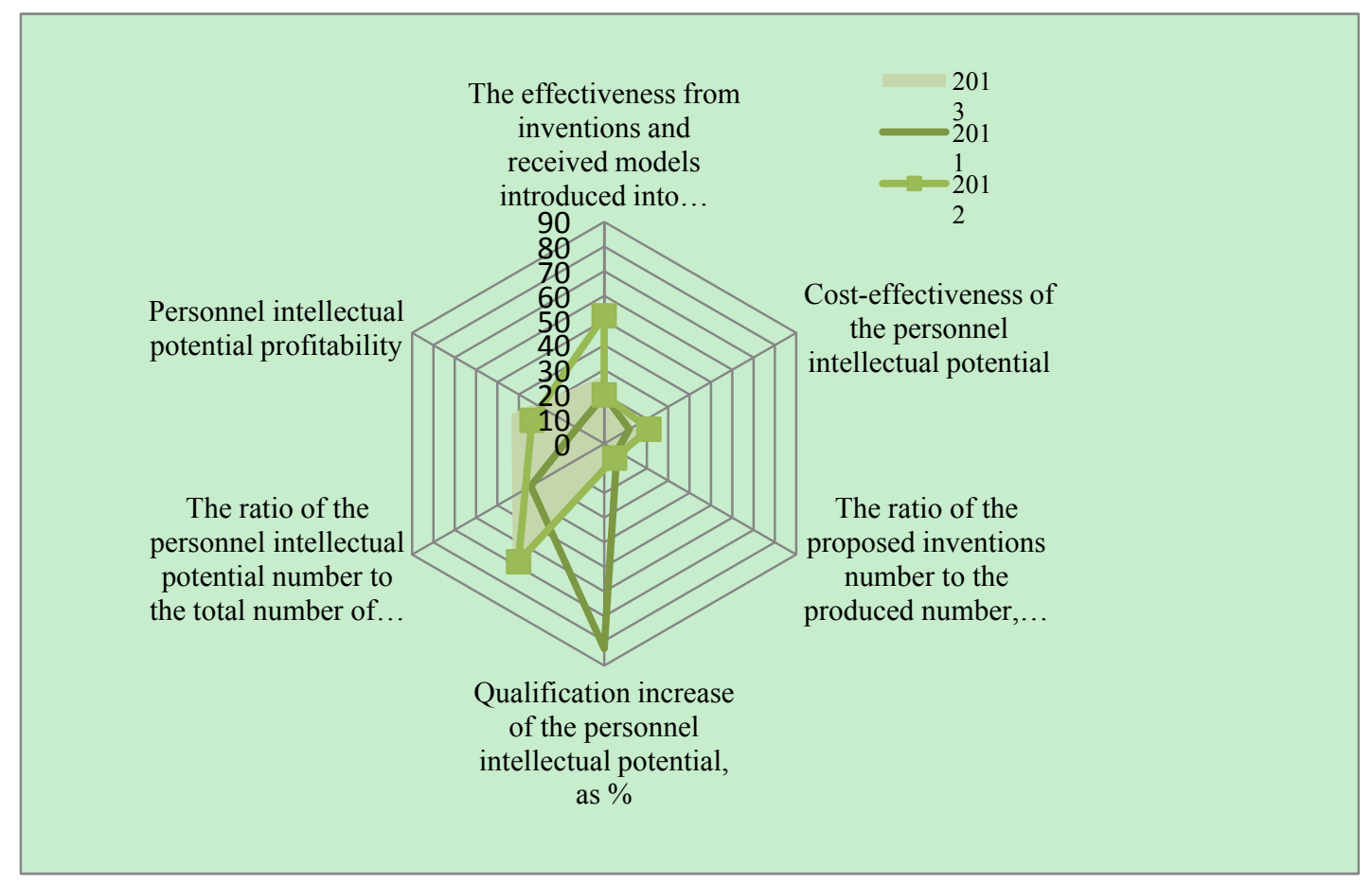

Figure 3. Total evaluation of the personnel intellectual potential (PIP) in JSC "Tatneft"

Total evaluation of the personnel intellectual potential in JSC "Tatneft" allows to determine the critical dynamics of the process, to identify problem areas and the need to improve some aspects of personnel management. In particular, the effectiveness of the personnel intellectual potential training, which was conducted in 2011, clearly manifested in cost-effectiveness of personnel intellectual potential realization in 2013, which underlines the profitability and effectiveness of professional development programme, but these manifestations require development of the optimum timing for realization of acquired knowledge, that is, the accumulation time for personnel intellectual potential.

There was delivered a survey to assess the level of employee satisfaction (96 people: employees, department heads, managers). Results of the survey show the increasing of employee satisfaction level, self-esteem, work motivation, corporate responsibility (in general by $23 \%$ ) compared to the period when there was not any evaluation and the personnel intellectual potential development. The results of the survey confirm the hypothesis of the study.

\section{Discussions}

An evaluation of the personnel intellectual potential of the industrial enterprise was carried out on some management positions provided by JSC "Tatneft". The expansion of assessment indicators allows to estimate the industrial enterprises intellectual potential level more authentically, that will create additional opportunities for its development.

In regards of importance of material elements of production, the personnel intellectual potential acts as an important factor of scientific and technological progress and innovative development, growth of labor productivity, improving the usage of fixed-capital and current assets, the quality improvement of products and also determines the effectiveness of all aspects of production and commercial activities of a market participant. 


\section{Conclusions}

Implementation in the management the approach to identification, evaluation and development of the industrial enterprise personnel intellectual potential determines the economic efficiency and increase the competitiveness.

This author's technique will allow to estimate reliably the level of the industrial enterprise personnel intellectual potential that will create additional opportunities for its development and will help to meet the needs of an intellectual, that is the best usage of one's knowledge and their expansion, as well as their maximum accumulation, rational development and usage that, in turn, will accelerate the development of innovative technologies and will increase the labor productivity.

\section{Acknowledgments}

The authors thank all participants of this study for their kind cooperation.

\section{References}

Anisimova, I. A. (2010). The concept of forming a system audit of personnel management in the organization. Personnel, 11, 19-24.

Bovin, A. A. et al. (2009). Managing Innovation in Organizations. Moscow: Publishing House "Omega-L".

Bukhalkov, M. I. (2005). Personnel management: The development of labor potential (p. 192). Moscow: INFRA-M Publisher.

Chernoles, G. V. (2008). Intellectual capital in the structure of the company's assets, based on new knowledge: The nature, content and functional role of its components. Innovations, 9, 108-113.

Egorshin, A. P. (2011). The organization of the personnel: The textbook (p. 320). Moscow: INFRA-M Publisher.

Grishina, T. V. (2011). The auditor's examination of social responsibility in the field of social and labor relations: Tools and methodologies (p. 207). Moscow Publishing house "ATIS".

Hadasevich, N. R. (2010). Capacity building within the organization. Personnel, 1, 6-11.

Kibanov, A. J., \& Durakova, I. B. (2007). Upravlenie staff of the organization: Strategy, marketing, internationalization (p. 301). Moscow: INFRA-M Publisher.

Lavrentiev, V. A., \& Sharina, A. V. (2009). Intellectual potential of the enterprise: Concept, structure and direction of its development. Creative Economy, 2, 83-89.

Mahankova, T. P. (2010). The nature and evolution of concepts and views on human resources. In the world of scientific discovery, 1-2, 67-72.

Milner, B. Z. (2008). Organization theory (p. 453). Moscow: INFRA-M Publisher.

Muhamedyarov, A. M. (2008). Innovation Management (p. 176). Moscow: INFRA-M Publisher.

Noskova, M. V. (2010). The theoretical model of economic development category "human resources". Herald Altai State Agrarian University, 2, 89-93.

Stewart, T. A. (2007). Intellectual capital. New source of wealth organization (p. 368). Moscow: Generation Publisher.

\section{Copyrights}

Copyright for this article is retained by the author(s), with first publication rights granted to the journal. This is an open-access article distributed under the terms and conditions of the Creative Commons Attribution license (http://creativecommons.org/licenses/by/3.0/). 